\title{
New data on some Russian herpetologists. Communication 3
}

\author{
I. V. Doronin
}

Zoological Institute, Russian Academy of Sciences

1 Universitetskaya Emb., Saint Petersburg 199034, Russia

Article info

Short Communication

https://doi.org/10.18500/1814-6090-2021-213-4-123-131

Received 30 July 2021 revised 30 August 2021, accepted 31 August 2021

This is an open access article distributed under the terms of Creative Commons Attribution 4.0 International License (CC-BY 4.0)

\begin{abstract}
Unknown biographic data about I. S. Darevsky, D. B. Krasovsky, and S. A. Chernov are presented. This information was obtained during work with the museum collection of the Gorsky State Agrarian University (Vladikavkaz), that of E. N. Pavlovsky's Chair of Biology at S. M. Kirov Military Medical Academy, and the archive of the Zoological Institute of the Russian Academy of Sciences.

Keywords: history of science, I. S. Darevsky, S. A. Chernov, D. B. Krasovsky
\end{abstract}

Acknowledgments: The study was carried out in the framework of the State Theme of the Zoological Institute, Russian Academy of Sciences (No. AAAA-A19-119020590095-9).

For citation: Doronin I. V. New data on some Russian herpetologists. Communication 3. Current Studies in Herpetology, 2021, vol. 21, iss. 3-4, pp. 123-131 (in Russian). https://doi.org/ 10.18500/1814-6090-2021-21-3-4-123-131

\section{REFERENCES}

Ananjeva N. B., Doronin I. V. Sergey Alexandrovich Chernov (1903 - 1964): Biography of herpetologist. Proceedings of the Zoological Institute RAS, 2020, vol. 324, no. 1, pp. 7-40 (in Russian).

Boehme L. B, Krasovsky D. B., Chernov S. A. Materials for the knowledge of the fauna of vertebrates of the Ingush Autonomous Region. Proceedings of the Ingush Research Institute of Regional Studies, 1929, iss. 2, pp. 47-111 (in Russian).

Vereshchagin N. K. B. Caucasus. III. Reptiles Reptilia. In: B. S. Vinogradov, ed. Zhivotnyi mir SSSR. T. V. Gornye oblasti Evropeiskoi chasti SSSR [Fauna of the USSR. Vol. V. Mountain areas of the European part of the USSR]. Moscow, Leningrad, Izdatel'stvo AN SSSR, $1958 a$, pp. 261-280 (in Russian).

Vereshchagin N. K. B. Caucasus. IV. Amphibians Amphibia. In: B. S. Vinogradov, ed. Zhivotnyi mir SSSR. T. V. Gornye oblasti Evropeiskoi chasti SSSR [Fauna of the USSR. Vol. V. Mountain areas of the European part of the USSR]. Moscow, Leningrad, Izdatel'stvo AN SSSR, $1958 a$, pp. 281-286 (in Russian).

Darevsky I. S. Systematics and ecology of rock lizards Lacerta saxicola Eversmann, inhabiting in Armenia. Zoological Collection of the Academy of Sciences of the Armenian SSR. Materials for the Study of the Fauna of the Armenian SSR, 1957 a, no. 10, pp. 27-57 (in Russian).

Darevsky I. S. The Fauna of Reptiles in Armenia and Its Zoogeographic Analysis. Thesis Diss. Cand. Sci. (Biol.). Yerevan, 1957 b. 28 p. (in Russian).

Darevsky I. S. Systematic status of Rhynchocalamus melanocephalus satunini Nik. (Serpentes, Colubri- dae) previously included in the genus Oligodon. Zoologicheskii zhurnal, 1970, vol. 49, no. 11, pp. 1685-1690 (in Russian).

Darevsky I. S. Endangered and rare species of amphibians and reptiles of Transcaucasia. In: A. S. Avetyan, ed. Fauna and Its Protection in the Republics of Transcaucasia: Materials of the Conference. Yerevan, Izdatel'stvo AN Armianskoi SSR, 1975, pp. 64-67 (in Russian).

Darevsky I. S., Szczerbak N. N. Acclimatization of parthenogenetic lizards in Ukraine. Priroda, 1968, no. 5, pp. 93 (in Russian).

Doronin I. V. New data on some russian herpetologists. Current Studies in Herpetology, 2015, vol. 15, iss. 3-4, pp. 160-166 (in Russian).

Doronin I. V. New data on some russian herpetologists. Communication 2. Current Studies in Herpetology, 2020, vol. 20, iss. 1-2, pp. 65-76 (in Russian). https://doi.org/10.18500/1814-6090-2020-20-1-2-65-76

Krasovsky D. B. Materials for the knowledge of the fauna Reptilia and Amphibia of the Khasav-Yurt district of the Daghestanskaya S.S.R. News of the Gorsk Pedagogical Institute, 1928, vol. 4, pp. 219-228 (in Russian).

Krasovsky D. B. Materials to the knowledge of the fauna of terrestrial vertebrates Rutul canton of the Daghestanskaya ASSR. News of the 2nd North Caucasian Pedagogical Institute named Gadiev, 1932, vol. 9, pp. 185-218 (in Russian).

Krasovsky D. B. Materials for the knowledge of the fauna of amphibians and reptiles of the Caucasian State Reserve. News of the 2nd North Caucasian Pedagogical Institute, 1933, vol. 10. pp. 89-95 (in Russian).

\footnotetext{
${ }^{\square}$ Corresponding author. Laboratory of Herpetology of Zoological Institute, Russian Academy of Sciences, Russia.

ORCID and e-mail address: Igor V. Doronin: https://orcid.org/0000-0003-1000-3144, Igor.Doronin@zin.ru.
} 
Kuzmin S. L. Amphibians of the Former USSR. Moscow, KMK Scientific Press, 2012. 370 p. (in Russian).

Lotiev K. Yu. Herpetofauna of the North Ossetia and problem of rare species protection at the legislative level. In: Environmental Safety and Conservation of Genetic Resources of Plants and Animals in Russia and Adjacent Territories: Materials of the All-Russian with International participation scientific conference, dedicated to the 100th anniversary of the North Ossetian State University named after Kosta Levanovich Khetagurov. Vladikavkaz, IPTs Severo-Osetinskogo gosudarstvennogo universiteta, 2021, pp. 130-139 (in Russian).

Talyzin F. F. Sekrety prirody [Secrets of Nature]. Moscow, Mysl Publ., 1973. 191 p. (Stories About Nature) (in Russian).

Chernov S. A. To the knowledge of the herpetofauna of Armenia and Nakhichevan region. Scientific Notes of the North Caucasian Institute of Regional Stu- dies, 1926, vol. 1, pp. 63-72 (in Russian).

Chernov S. A. 1929. Materials for the knowledge of the fauna of Amphibia et Reptilia of mountain Ingushia. Proceedings of the Ingush Research Institute of Regional Studies, 1929, iss. 2, pp. 93-110 (in Russian).

Shapoval A. I. The personal collection of Sergey Jacques Paramonov as a source for the research of the biography and scientific activities of the scientist. Manuscript and Book Heritage of Ukraine, 2014, vol. 18, pp. 91-112 (in Ukrainian).

Shergalin E. E. Bright memory of ornithologist and teacher Dmitry Borisovich Krasovsky (1908-1938). Russian Journal of Ornithology, 2017, vol. 26, expressissue 1433, pp. 1575-1584 (in Russian).

Tuniyev B. S., Orlov N. L., Ananjeva N. B., Aghasyan A. L. Snakes of the Caucasus: Taxonomic Diversity, Distribution, Conservation. St. Petersburg, Moscow, KMK Scientific Press, 2019. 276 p. 